\title{
Insectes, vers, protéases et apoptose
}

L'apoptose ou mort cellulaire programmée joue un rôle essentiel dans le développement et l'homéostasie chez les organismes multicellulaires et constitue un moyen de défense contre les virus et oncogènes. Le gène $p 35 \mathrm{du}$ baculovirus AcMNPV (Autographa californica nuclear polyhedrosis virus) code pour une protéine inhibitrice de l'apoptose dans de nombreux modèles biologiques tels que des lignées cellulaires de mammifères et d'insectes, des embryons et yeux de Drosophila melanogaster transgénique et le nématode Caenorhabditis elegans. Un travail fait en collaboration entre des équipes de BASF (Worcester, Ma, USA), d'Athens (GA, USA) et de Winnipeg (Manitoba, Canada) démontre que la protéine p35 bloque l'apoptose en inhibant directement une famille de protéases, les ICE (interleukin-1 $\beta$ converting enzyme) [1]. Le rôle apoptotique de l'ICE $\left(m / s n^{\circ} 2\right.$, vol. 10, p. 232 ; $n^{\circ} 7$, vol. 11, p. 1053) [2] et des protéines apparentées $\left(\mathrm{m} / \mathrm{s} n^{\circ} 10\right.$, vol. $11, p .1487)$ avait été récemment mis en évidence par surexpression de l'enzyme dans des lignées de cellules de mammifères et d'insectes. Si l'on cotransfecte des plasmides codant pour p35 et pour ICE dans des cellules Cos recombinantes, exprimant de façon constitutive le précurseur de l'interleukine $1 \beta$, le proIL1 $\beta$, la sécrétion de IL1 $\beta$ mûre est fortement inhibée. p35 ne modifie ni la synthèse de ICE, ni celle de proIL1 $\beta$ mais inhibe l'activité protéasique de ICE. Cet effet inhibiteur est tout à fait spécifique de la famille des ICE. L'action inhibitrice de p35 sur les ICE s'accompagne d'un clivage de la protéine p35 en un fragment de $25 \mathrm{kDa}$ au site de clivage Asp-Gly, site de clivage préférentiel connu pour les ICE. Un complexe stable entre ICE et ce fragment a pu être isolé, suggérant ainsi la nature irréversible du mécanisme inhibiteur de p35. Enfin, le propre clivage protéolytique de ICE, nécessaire à son activité enzymatique dans la cellule, est bloqué en présence de p35, ce qui laisse penser que, in vivo, p35 peut bloquer l'autoactivation de ICE et empêcher ainsi l'action apoptotique de l'enzyme. Le mécanisme antiapoptotique de p35 via l'inhibition d'une enzyme ICE-like a pu être également démontré dans des cellules d'insectes, suggérant ainsi le rôle essentiel et ancestral des protéines de la famille des ICE dans l'induction de l'apoptose. Caenorhabditis elegans synthétise une protéine à cystéine, homologue de ICE et impliquée elle aussi dans l'apoptose, Ced-3 (m/s $n^{\circ} 2$, vol. 10, p. 232); récemment un effet inhibiteur de p35 sur Ced-3 a été rapporté [3]. L'action de p35 sur l'enzyme nécessite la présence d'un site de clivage spécifique de Ced-3 et des protéines apparentées à Ced-3 présentes chez les vertébrés. L'introduction d'un tel site de clivage dans une protéine n'ayant pas d'activité apoptotique chez $C$. elegans confère à cette protéine mutée une fonction antiapoptotique dans ce modèle. Ces éléments suggèrent fortement un rôle de substrat compétitif vis-à-vis des protéases à cystéine.

La mise en jeu d'une activité protéolytique dans une étape critique du mécanisme conduisant à l'apoptose démontre la nécessité de l'expression de gène(s) spécifique(s) de cette fonction cellulaire. La protéine p35 du baculovirus n'a, à ce jour, aucun homologue connu. L'identification d'une telle protéine permettra sans doute une meilleure compréhension des phénomènes régulateurs du choix entre vie et mort dans les cellules de mammifères.

B.A.
1. Bump NJ, Hackett M, Hugunin M, et al. (17 auteurs). Inhibition of ICE family proteases by baculovirus antiapoptotic protein p35. Science $1995 ; 269$ : 1885-8.

2. Martinou J. La mort cellulaire programmée dans le système nerveux. médecine/sciences 1995 ; $11: 367-73$.

3. Xue D, Horvitz HR. Inhibition of the Caenorhabditis elegans cell death protease CED- 3 by a CED-3 cleavage site in baculovirus p35 protein. Nature 1995; 377 : 248-51.
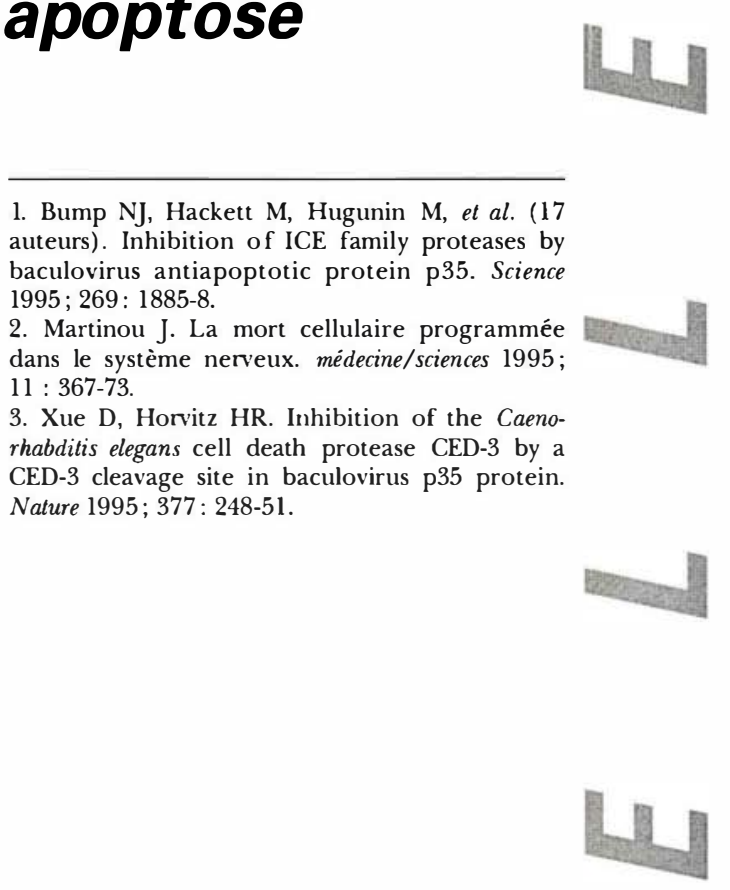